\title{
Peran Orang Tua Dalam Perkembangan Ketrampilan Awal Literasi Anak
}

\author{
Hafidz Triantoro Aji Pratomo ${ }^{1^{*}}$, Muryanti ${ }^{2}$ \\ 1,2 Jurusan Terapi Wicara, Poltekkes Kemenkes Surakarta \\ *Email: hafidzpoltekkes@gmail.com
}

\begin{abstract}
Background: Literacy is a supporting component of children's academic success. Literacy ability is influenced by interdependent language skills. Limitations on early literacy skills increase the chance of academic process obstacles at school age. The role of parents is crucial in the child's development process especially in literacy. Aim this study is to describe correlation between parental variabels and early literacy skills. Methods: This cross sectional research was conducted with a survey approach. The instrument was developed to explore demographic information, socioeconomic status, and the role of parents in developing early literacy skills. Statistic descriptive and correlation study was conducted to analyse 180 respondent data. Results: The role of parents has contributed to the development of early literacy skills. Parental history, mother's education, and language activities have a positive relationship with the development of early literacy skills. Conclusions: The role of parents is one of the multivariate variables that play a role in the development of early literacy skills. Further search is needed to see the extent of the role of parents in carrying out specific activities that are relevant to children's literacy abilities.
\end{abstract}

Keywords: parenting, literacy, language, rural

\section{PENDAHULUAN}

Kemampuan
Ketrampilan

awal literasi awal literasi merupakan kemampuan yang menunjang keberhasilan akademik anak. Pencapaian kemampuan awal literasi menjadi indikator yang baik dalam keberhasilan dalam pemahaman membaca anak (Skebo et al., 2010) serta menjadi indikator kesiapan anak (Pentimonti et al., 2016). Kemampuan memahami bacaan sangat penting karena sebagian besar bahan pelajaran disajikan dalam bentuk ragam tulisan. Penting untuk mengupayakan keberhasilan pencapaian ketrampilan awal literasi pada masa prasekolah. Munculnya permasalahan perkembangan awal literasi menjadi prediktor adanya permasalahan belajar pada tingkat lanjut (Glogowska \& Yorkshire, 2006). Ketrampilan awal literasi terhubung langsung dengan kompetensi bahasa anak. Kemampuan bahasa yang terdiri dari bentuk, isi, dan penggunaan bahasa merupakan modalitas yang berkaitan langsung dengan dalam perkembangan literasi (Connor, 2008). dipengaruhi oleh komponen multivariabel. Salah satu variabel yang mempengaruhi ketrampilan awal literasi adalah peran orang tua (Bingham et al., 2017; Pratt et al., 2015; Rowea et al., 2016; van Kleeck \& Melanie Schuele, 2010). Orang tua berperan dominan dalam perkembangan bahasa anak. Peran mereka menjadi satu dari tiga peran utama dalam perkembangan bahasa (Weigel et al., 2007). Pembelajaran awal literasi didominasi oleh metode diktatik phonic dibandingkan penguatan kemampuan phonemic awareness (Schuele \& Boudreau, 2008; Shanahan, 2005). Pendekatan ini mentitikberatkan pada profil grafem sehingga mengecilkan kesempatan siswa untuk mempelajari bunyi bahasa. Usia pra sekolah merupakan usia penting dalam ketrampilan literasi. Ketrampilan literasi pada tahapan ini antara lain phonemic awareness, phonics, fluency, dan kosakata (Connor, 2008; Shanahan, 2005). 
Data menunjukkan bahwa sebagian dari anak prasekolah mengalami keterlambatan ketrampilan awal literasi. Permasalahan literasi yang ditemukan menunjukkan adanya hubungan antara bahasa dan literasi (Cabell et al., 2011; Ren et al., 2019). Lebih lanjut, Indonesia merupakan salah satu negara dengan capaian literasi yang rendah. Programme for International Student Assessment menunjukkan bahwa prosentase performa rendah literasi di angka $70 \%$ (Badan Penelitian dan Pengembangan dan Perbukuan Kemendikbud RI, 2019). Hal ini merupakan tantangan dalam mengembangkan budaya literasi di Indonesia. Fakta ini menunjukkan bahwa peningkatan ketrampilan awal literasi sangat diperlukan. Peningkatan ketrampilan awal literasi bisa dimulai dengan melihat seberapa besar orang tua berperan.

Meskipun peran orang tua memiliki hubungan positif dengan perkembangan literasi (Pratt et al., 2015), peran orang tua dalam proses perkembangan literasi mempengaruhi secara multivariabel (Nag et al., 2019). Artinya tidak ada spesifisitas tertantu yang paling berpengaruh dalam perkembangan literasi anak. Diperlukan penelusuran mengenai variabel yang memerlukan kehadiran orang tua dalam pengembangan ketrampilan awal literasi. Penelitian ini dilakukan untuk mengetahui pengaruh orang tua terhadap perkembangan kemampuan awal literasi di daerah pedesaan.

\section{METODE PENELITIAN}

Penelitian dilakukan selama 3 bulan pada bulan April 2019 sampai dengan bulan Juni 2019. Pengambilan data dilakukan di Kecamatan Gondangrejo
Kabupaten Karanganyar. Desain penelitian menggunakan pendekatan crosssectional. Sampel berpasangan merupakan siswa Taman Kanak-kanak beserta orang tua. Responden yang terlibat dalam penelitian berjumlah 180 dengan metode sampling total sampling.

Instrumen penelitian menggunakan kuesioner diadaptasi dari skrining informal (Shipley \& McAfee, 2009) yang telah dimodifikasi. Riwayat orang tua dikategorikan dengan dikotomi memiliki dan tidak memiliki riwayat permasalahan komunikasi. Bahasa sehari-hari yang digunakan menggunakan dikotomi bilingual dan monolingual. Pendidikan ibu didasarkan pada lama waktu menempuh pendidikan di atas 9 tahun dan di bawah sama dengan 9 tahun. Usia ibu menggunakan patokan 35 tahun sebagai acuan dikotomi.

Aktivitas bahasa terbagi menjadi dua kelompok yakni aktivitas bahasa baik dan aktivitas bahasa kurang. Ketrampilan awal literasi diukur menggunakan skala guttman dengan nilai 1 jika dikuasai dan nilai 0 jika belum dikuasai. Pembagian kategori didasarkan pada nilai rata-rata. Analisis data menggunakan aplikasi SPSS for Windows 18. Analisis statistik untuk mengetahui hubungan antar variabel menggunakan analisis regresi logistik.

\section{HASIL PENELITIAN}

Responden yang melengkapi kuesioner berjumlah 180 anak. Distribusi frekeunsi disusun berdasarkan jenis kelamin anak, pendidikan ibu, bahasa yang digunakan, dan riwayat permasalahan komunikasi yang dialami oleh orang tua. Tabel di bawah menunjukkan bahwa perempuan mendominasi sampel penelitian. Sebagian besar ibu memiliki Pendidikan menengah 
ke bawah. Mayoritas bahasa sehari-hari yang digunakan adalah bahasa Jawa. Orang tua dengan riwayat permasalahan komunikasi memiliki prosentase sebesar $10 \%$ dari total responden. Analisis bivariat digunakan untuk melihat korelasi antara variabel yang memiliki hubungan dengan ketrampilan awal literasi. Analisis bivariat dilakukan untuk melihat hubungan riwayat permasalahan komunikasi orang tua, penggunaan bahasa, Pendidikan ibu, usia ibu, dan aktivitas bahasa dengan perkembangan ketrampilan awal literasi anak.

Tabel 1. Distribusi Frekuensi

\begin{tabular}{llcc}
\hline Komponen & & n & \% \\
\hline Jenis Kelamin & Laki-laki & 89 & 49 \\
Pendidikan ibu & Perempuan & 91 & 51 \\
& Sekolah Dasar & 36 & 20 \\
& Sekolah Menengah Pertama & 49 & 27 \\
& Sekolah Menengah Atas & 78 & 43 \\
& Diploma & 7 & 4 \\
& Sarjana & 8 & 4 \\
Bahasa yang digunakan & Pascasarjana & 2 & 1 \\
& Bahasa Jawa & 103 & 57 \\
& Bahasa Indonesia & 4 & 2 \\
Riwayat permasalahan & Campuran Bahasa Jawa dan Indonesia & 73 & 41 \\
& Memiliki riwayat permasalahan & 18 & 10 \\
& Tidak memiliki riwayat permasalahan & 162 & 90 \\
\hline
\end{tabular}

Riwayat keluarga terdiri dari dua artinya anak hanya menggunakan satu kategori dengan memiliki riwayat bahasa, yakni bahasa Jawa atau bahasa permasalahan dan tidak memiliki riwayat Indonesia saja. Sedangkan bilingual permasalahan. Hubungan antara riwayat adalah anak yang menggunakan dua orang tua dengan kemampuan literasi bahasa. Hubungan antara penggunaan dihubungkan dengan uji Chi Square. Hasil bahasa dan ketrampilan awal literasi analisis menunjukkan bahwa riwayat dilakukan dengan melakukan uji Chi orang tua memiliki hubungan dengan Square. Hasil uji menunjukkan nilai OR ketrampilan awal literasi anak. Orang tua sebesar 1.85 dengan nilai p 0.174. Secara dengan riwayat permasalahan komunikasi memiliki anak dengan ketrampilan literasi di bawah rata-rata. Nilai p sebesar 0.019 menunjukkan bahwa prasyarat untuk dilakukan analisis regresi terpenuhi.

Penggunaan bahasa terbagi menjadi monolingual dan bilingual. Monolingual statistik tidak ditemukan adanya hubungan antara penggunaan bahasa sehari-hari dengan ketrampilan awal literasi. Apabila dilihat dari nilao odds, penggunaan bahasa memiliki peluang dalam mempengaruhi perkembangan ketrampilan awal literasi anak. 
Tabel 2. Hubungan Antara Riwayat Permasalahan dengan Ketrampilan Awal Literasi.

\begin{tabular}{|c|c|c|c|c|}
\hline \multirow{2}{*}{ Variabel } & \multicolumn{2}{|c|}{ Ketrampilan Awal Literasi } & \multirow{2}{*}{ OR } & \multirow{2}{*}{ Nilai $p$} \\
\hline & Di bawah rata-rata & Di atas rata-rata & & \\
\hline \multicolumn{5}{|l|}{ Riwayat orang tua } \\
\hline Memiliki riwayat & $13(72)$ & $5(28)$ & \multirow{2}{*}{5.90} & \multirow{2}{*}{$0.019 *$} \\
\hline Tidak memiliki riwayat & $70(43)$ & $92(57)$ & & \\
\hline \multicolumn{5}{|l|}{ Penggunaan Bahasa } \\
\hline Monolingual & $43(42)$ & $60(58)$ & \multirow{2}{*}{1.85} & \multirow{2}{*}{$0.174^{\wedge}$} \\
\hline Bilingual & $40(52)$ & $37(48)$ & & \\
\hline \multicolumn{5}{|l|}{ Pendidikan ibu } \\
\hline Kurang dari 9 tahun & $50(59)$ & $35(41)$ & 10.5 & \multirow{2}{*}{$0.001 *$} \\
\hline Lebih dari 9 tahun & $33(35)$ & $62(65)$ & 6 & \\
\hline \multicolumn{5}{|l|}{ Usia ibu } \\
\hline Lebih dari 35 tahun & $25(51)$ & $24(49)$ & \multirow{2}{*}{0.65} & \multirow{2}{*}{0.419} \\
\hline Kurang dari 35 tahun & $58(44)$ & $73(56)$ & & \\
\hline \multicolumn{5}{|l|}{ Aktivitas bahasa } \\
\hline Kurang & $56(55)$ & $46(45)$ & \multirow{2}{*}{7.39} & \multirow{2}{*}{$0.007 *$} \\
\hline Baik & $27(35)$ & $51(65)$ & & \\
\hline
\end{tabular}

Keterangan : *siginifikan; ${ }^{\wedge}$ diikutkan dalam analisis multivariat.

Tabel 3. Hasil Analisis Multivariat

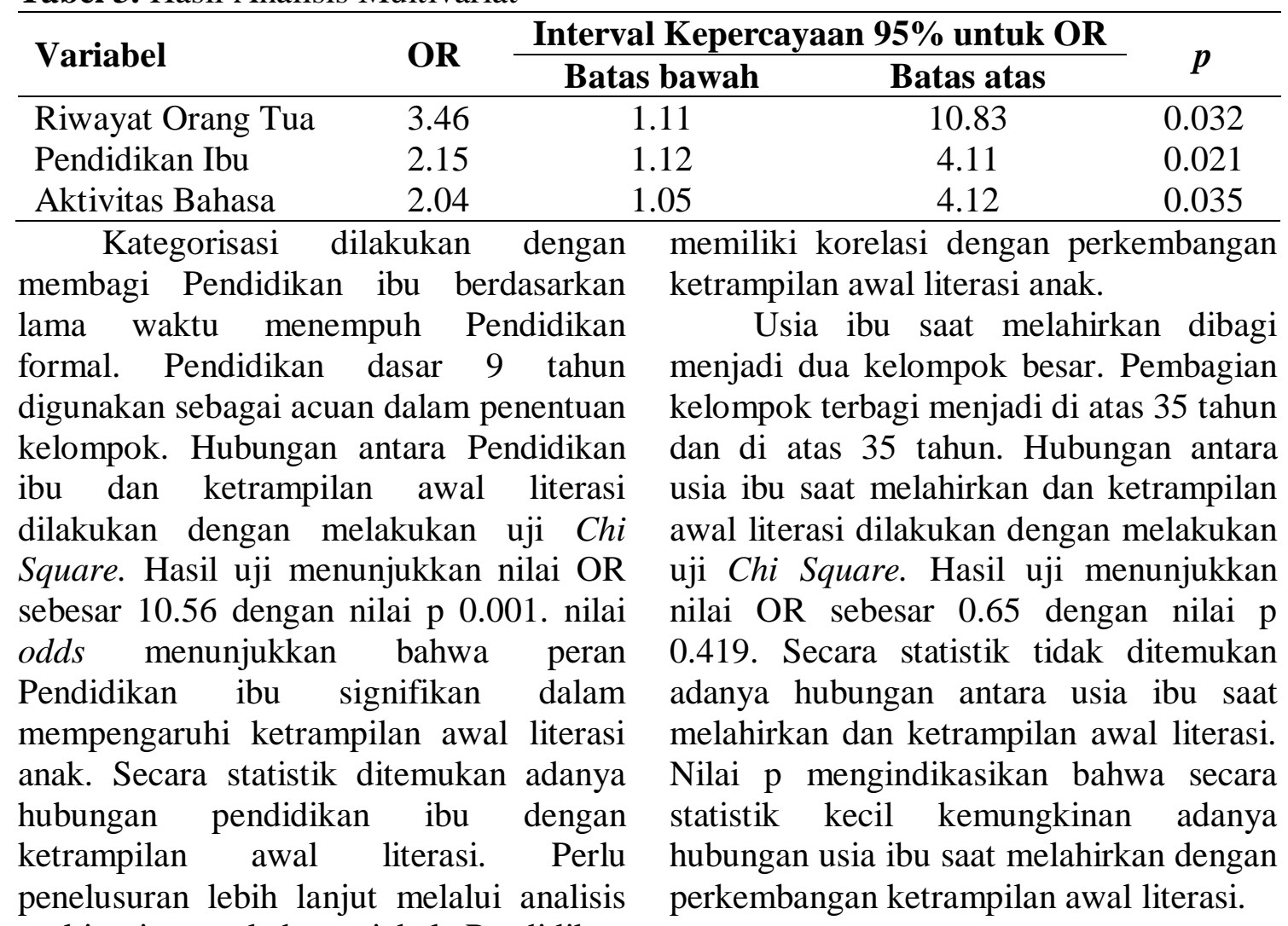
multivariat apakah variabel Pendidikan 
Pembagian aktivitas bahasa dilihat dari nilai rata-rata. Aktivitas bahasa yang memiliki nilai di atas rata-rata dikatakan baik. Hubungan antara aktivitas bahasa orang tua dan ketrampilan awal literasi dilakukan dengan melakukan uji Chi Square. Hasil uji menunjukkan nilai OR sebesar 7.39 dengan nilai p 0.007. Secara statistik ditemukan adanya hubungan antara penggunaan bahasa sehari-hari dengan ketrampilan awal literasi. Nilai odds menunjukkan bahwa aktivitas bahasa memiliki peluang yang tinggi dalam pengembangan ketrampilan awal literasi.

Statistik menunjukkan bahwa analisis multivariat menunjukkan adanya hubungan antara peran orang tua dengan ketrampilan awal literasi. Hasil analisis menempatkan riwayat orang tua, Pendidikan ibu, dan aktivitas bahasa memiliki keterkaitan dengan ketrampilan awal literasi anak. Hasil analisis ditunjukkan pada tabel 3 .

Tabel di atas menunjukkan bahwa Odds Ratio tertinggi adalah riwayat orang tua. Artinya orang tua yang memiliki riwayat permasalahan komunikasi memiliki risiko yang tertinggi untuk memiliki anak dengan ketrampilan literasi di bawah rata-rata daripada variabel lain.

\section{PEMBAHASAN}

Riwayat orang tua memiliki hubungan yang kuat dengan ketrampilan awal literasi anak. Orang tua dengan riwayat permasalahan komunikasi memiliki risiko untuk memiliki anak dengan ketrampilan awal literasi di bawah rata-rata. Riwayat orang tua dengan permasalahan komunikasi memiliki dua kemungkinan dalam mempengaruhi ketrampilan awal literasi anak. Pertama, riwayat permasalahan komunikasi muncul karena adanya hipotesis pada variabel penurunan permasalahan. Kedua, permasalahan komunikasi pada orang tua menyebabkan adanya limitasi pada akses stimulasi dini. Secara herediter, belum ada bukti bahwa variabel genetik memiliki pengaruh yang kuat dalam mempengaruhi perkembangan literasi anak. Riwayat keluarga menjadi salah satu faktor risiko untuk gangguan bahasa perkembangan (Bishop et al., 2017). Artinya orang tua dengan riwayat permasalahan bahasa memiliki risiko untuk memiliki anak dengan gangguan bahasa perkembangan. Secara klinis belum dapat dibuktikan adanya informasi mengenai gangguan yang bersifat genetik. Kajian menunjukkan bahwa terdapat korelasi antara variabel gen dengan permasalahan komunikasi. Literatur menunjukkan bahwa permasalahan bahasa dan Disleksia memiliki keterkaitan dengan jenis gen secara spesifik (Kang \& Drayna, 2011). Hasil ini memunculkan dugaan bahwa riwayat orang tua dengan permasalahan komunikasi memiliki keterkaitan genetik dengan ketrampilan awal literasi.

Orang tua dengan permasalahan komunikasi memiliki tantangan dalam interaksi komunikasi dengan anak. Limitasi komunikasi yang dialami orang tua mengakibatkan hambatan akusisi model bahasa. Model bahasa penting untuk memperkuat capaian akuisisi bahasa anak. Bahkan dalam kasus spesifik, keterlibatan orang tua untuk melakukan aktivitas khusus memberikan dampak positif terhadap perkembangan kosakata anak (Girolametto et al., 1996). Orang tua dengan akses komunikasi yang baik akan memberikan dampak positif dalam perkembangan ketrampilan awal literasi.

Pendidikan ibu memiliki kontribusi dalam mempengaruhi perkembangan ketrampilan awal literasi. Pendidikan ibu 
memiliki pengaruh yang kuat dalam pengetahuan tentang proses tumbuh kembang anak. Pengetahuan yang cukup memungkinkan adanya persepsi positif tentang proses akuisisi suatu ketrampilan komunikasi (Von Der Lippe, 1999). Pendidikan ibu menjadi faktor risiko dan faktor protektif permasalahan komunikasi. Pendidikan ibu yang tinggi merupakan faktor protektif dalam perkembangan kemampuan komunikasi (McLeod \& Harrison, 2009). Sebaliknya. Pendidikan ibu yang rendah merupakan faktor risiko yang mempengaruhi anak untuk memiliki permasalahan komunikasi (Bishop et al., 2017). Isu status sosial ekonomi merupakan isu yang tidak bisa dilepaskan. Baik perkembangan literasi maupun bahasa, memiliki keterkaitan dengan variabel status sosial ekonomi orang tua keluarga. Keluarga dengan status sosial ekonomi yang baik memiliki peluang lebih tinggi dalam mengawal proses perkembangan bahasa dan literasi (Miser \& Hupp, 2012; Nag et al., 2019; Richels et al., 2013; Stanton-chapman et al., 2004; van Kleeck \& Melanie Schuele, 2010; Von Der Lippe, 1999). Semakin tinggi Pendidikan juga memberikan peluang pada akses perkembangan komunikasi yang lebih baik. Hal ini dibuktikan Pratomo et al., (2016) yang menemukan adanya korelasi positif antara pendidikan dan kemampuan bahasa anak. artinya temuan ini menguatkan temuan yang sudah dilakukan. Selain itu pengaruh SES juga sudah dibuktikan memberikan dampak yang besar pada perkembangan bahasa anak (Noble et al., 2012; Stantonchapman et al., 2004; Vernon-Feagans et al., 2008).

Aktivitas bahasa merupakan faktor kunci dalam perkembangan ketrampilan awal literasi anak. Aktivitas bahasa yang baik memberikan akses yang memadai dalam pembelajaran bahasa anak. Anak yang memperoleh stimulasi yang baik dapat mengembangkan kemampuan secara aktif. Bukti menunjukkan bahwa interaksi orang tuda dalam bookshare reading memberikan dampak positif dalam perkembangan ketrampilan literasi (Bingham et al., 2017; van Kleeck \& Melanie Schuele, 2010; Vernon-Feagans et al., 2008). Adanya penguatan orang tua dalam aktivitas literasi memberikan dampak positif dalam perkembangan literasi. Ketrampilan awal literasi yang terus menerus dikuatkan membuat pencapaian kemampuan membaca akan lebih mudah (Shanahan, 2005). Membentuk lingkungan keluarga dengan aktivitas bahasa yang baik memberikan peluang kepada anak untuk memiliki capaian positif dalam ketrampilan awal literasi anak (Bingham et al., 2017; Nag et al., 2019). Penelitian lain menunjukkan bahwa semakin banyak aktivitas bahasa akan memberikan peluang perkembangan bahasa yang baik (Pratomo et al., 2016). Dengan kemampuan bahasa yang mumpuni, peluang untuk memiliki ketrampilan literasi yang baik akan meningkat.

\section{KESIMPULAN DAN SARAN}

Penelitian ini menunjukkan bahwa peran orang tua memiliki pengaruh terhadap keterampilan awal literasi. Ketrampilan awal literasi merupakan kemampuan penting sebelum anak menggunakan kemampuan literasi secara akademis. Orang tua dengan riwayat permasalahan komunikasi, memiliki kemungkinan 3.4 kali lebih tinggi untuk memiliki anak dengan keterampilan awal literasi anak di bawah rata-rata. Pendidikan ibu memiliki kontribusi yang 
berhubungan dengan ketrampilan awal literasi anak. Ibu dengan Pendidikan rendah memiliki risiko 2.1 kali lebih tinggi untuk memiliki anak dengan ketrampilan literasi di bawah rata-rata.

Peran orang tua dalam memberikan aktivitas bahasa berhubungan dengan ketrampilan awal literasi. Aktivitas bahasa orang tua bersama anak di atas rata-rata memiliki peluang 2 kali lebih tinggi untuk memiliki anak dengan ketrampilan awal literasi di atas rata-rata. Perlu adanya penelusuran secara spesifik pada variabel aktivitas bahasa apa yang memiliki dampak terkuat dalam ketrampilan awal literasi. Penelusuran mengenai aktivitas bahasa secara spesifik diperlukan untuk meningkatkan upaya pengembangan ketrampilan awal literasi anak prasekolah.

\section{DAFTAR RUJUKAN}

Badan Penelitian dan Pengembangan dan Perbukuan Kemendikbud RI. (2019). Tentang PISA. Pusat Asesmen dan Pembelajaran Kementerian Pendidikan dan Kebudyaan Republik Indonesia. Di akses secara online dari https://puspendik.kemdikbud.go.id/t entang-pisa

Bingham, G. E., Jeon, H. J., Kwon, K. A., \& Lim, C. (2017). Parenting styles and home literacy opportunities: Associations with children's oral language skills. Infant and Child Development, 26(5), 1-18. https://doi.org/10.1002/icd.2020

Bishop, D. V. M., Snowling, M. J., Thompson, P. A., Greenhalgh, T., Adams, C., Archibald, L., Baird, G., Bauer, A., Bellair, J., Boyle, C., Brownlie, E., Carter, G., Clark, B.,
Clegg, J., Cohen, N., ContiRamsden, G., Dockrell, J., Dunn, J., Ebbels, S., ... Whitehouse, A. (2017). Phase 2 of CATALISE: a multinational and multidisciplinary Delphi consensus study of problems with language development: Terminology. Journal of Child Psychology and Psychiatry and Allied Disciplines, 58(10), 10681080.

https://doi.org/10.1111/jcpp.12721

Cabell, S. Q., Justice, L. M., Konold, T. R., \& McGinty, A. S. (2011). Profiles of emergent literacy skills among preschool children who are at risk for academic difficulties. Early Childhood Research Quarterly, 26(1), 1-14. https://doi.org/10.1016/j.ecresq.2010. 05.003

Connor, C. M. (2008). Language and Literacy Connections for Children Who are African American. Perspectives on Communication Disorders and Sciences in Culturally and Linguistically Diverse (CLD) Populations, 15(2), 43-53. https://doi.org/10.1044/cds15.2.43

Girolametto, L., Pearce, P. S., \& Weitzman, E. (1996). Interactive focused stimulation for toddlers with expressive vocabulary delays. Journal of Speech, Language, and Hearing Research, 39(6), 12741283.

https://doi.org/10.1044/jshr.3906.127 4

Glogowska, M., \& Yorkshire, S. (2006). Early speech- and children: 
linguistic, literacy , and social outcomes. Developmental Medicine \& Child Neurology, 48, 489-494. https://doi.org/10.1017/S0012162206 001046

Kang, C., \& Drayna, D. (2011). Genetics of Speech and Language Disorders. Annual Review of Genomics and Human Genetics, 12(1), 145-164. https://doi.org/10.1146/annurevgenom-090810-183119

McLeod, S., \& Harrison, L. J. (2009). Epidemiology of Speech and Language Impairment in a Nationally Representative Sample of. Journal of Speech, Language, and Hearing Research, 52(5), 1213-1230.

Miser, T. M., \& Hupp, J. M. (2012). The Influence of Socioeconomic Status, Home Environment, and Childcare on Child Language Abilities. Current Psychology, 31(2), 144-159. https://doi.org/10.1007/s12144-012-

Nag, S., Vagh, S. B., Dulay, K. M., \& Snowling, M. J. (2019). Home language, school language and children's literacy attainments : A systematic review of evidence from low- and middle-income countries. Review of Education, 7(1), 91-150. https://doi.org/10.1002/rev3.3130

Noble, K. G., Houston, S. M., Kan, E., \& Sowell, E. R. (2012). Neural correlates of socioeconomic status in the developing human brain. Developmental Science, 15(4), 516527. https://doi.org/10.1111/j.14677687.2012.01147.x
Pentimonti, J. M., Murphy, K. A., Justice, L. M., Logan, J. A. R., \& Kaderavek, J. N. (2016). School readiness of children with language impairment: Predicting literacy skills from preliteracy and social-behavioural dimensions. International Journal of Language and Communication Disorders, 51(2), 148-161. https://doi.org/10.1111/14606984.12193

Pratomo, H. T. A., Adriani, R. B., \& Akhyar, M. (2016). Association Between Parental Education, Occupation, Income, Language Activity, and Language Proficiency in Children. Indonesian Journal of Medicine, 01(03), 152-159. https://doi.org/10.26911/theijmed.20 16.01.03.02

Pratt, A. S., Justice, L. M., Perez, A., \& Duran, L. K. (2015). Impacts of parent-implemented early-literacy intervention for Spanish-speaking children with language impairment. International Journal of Language and Communication Disorders, 50(5), 569-579. https://doi.org/10.1111/14606984.12140

Ren, L., Hu, B. Y., \& Wu, Z. (2019). Profiles of literacy skills among Chinese preschoolers: Antecedents and consequences of profile membership. Learning and Individual Differences, 69(1), 22-32. https://doi.org/10.1016/j.lindif.2018. 11.008

Richels, C. G., Johnson, K. N., Walden, T. A., \& Conture, E. G. (2013). 
Socioeconomic status, parental education, vocabulary and language skills of children who stutter. Journal of Communication Disorders, 46(4), 361-374.

https://doi.org/10.1016/j.jcomdis.201 3.07 .002

Rowea, M. L., Denmark, N., Harden, B. J., \& Stapleton, L. M. (2016). The Role of Parent Education and Parenting Knowledge in Children's Language and Literacy Skills among White, Black, and Latino Families. Infant and Child Development, 25, 198-220.

https://doi.org/10.1002/icd.1924

Schuele, C. M., \& Boudreau, D. (2008). Phonological awareness intervention: Beyond the basics. Language, Speech, and Hearing Services in Schools, 39(1), 3-20. https://doi.org/10.1044/01611461(2008/002)

Shanahan, T. (2005). The National Reading Panel Report: Practical Advice for Teachers. In Learning Point Associates. http://eric.ed.gov/ERICWebPortal/re cordDetail?accno=ED489535

Skebo, C. M., Lewis, B. A., Freebairn, L. A., Tag, J., Ciesla, A. A., \& Stein, C. M. (2010). Reading Skills of Students With Speech Sound Disorders at Three Stages of Literacy Development. Language, Speech, and Hearing Services in Schools, 44(4), 360-373. https://doi.org/10.1044/01611461(2013/12-0015)360
Stanton-chapman, T. L., Chapman, D. A., Kaiser, A. P., \& Hancock, T. B. (2004). Cumulative Risk and LowIncome Children's Language Development. 237, 227-237.

Van Kleeck, A., \& Melanie Schuele, C. (2010). Historical perspectives on literacy in early childhood. American Journal of Speech-Language Pathology, 19(4), 341-355. https://doi.org/10.1044/10580360(20 10/09-0038)

Vernon-Feagans, L., Pancsofar, N., Willoughby, M., Odom, E., Quade, A., \& Cox, M. (2008). Predictors of maternal language to infants during a picture book task in the home: Family SES, child characteristics and the parenting environment. Journal of Applied Developmental Psychology, 29(3), 213-226. https://doi.org/10.1016/j.appdev.2008 .02 .007

Von Der Lippe, a L. (1999). The impact of maternal schooling and occupation on child-rearing attitudes and behaviours in low income neighbourhoods in Cairo, Egypt. International Journal of Behavioral Development, 23(3), 703-729. https://doi.org/10.1080/01650259938 3766

Weigel, D. J., Lowman, J. L., \& Martin, S. S. (2007). Language development in the years before school: A comparison of developmental assets in home and child care settings. Early Child Development and Care, 177(6-7),719-734. https:/doi.org/10.10/0300443070379 